Teachers, which are members of the Institute, have unanimously ratified a change in the constitution under which members of the societies automatically become individual members, without additional subscriptions, of the Institute, thus creating a large unified professional body of physicists. The amended constitution and the new rules are printed in full. No change is made in the organisation, functions or activities of the member societies; but the way is opened for all persons interested in physies to play, individually, a greater part in the affairs and interests of physics, where these are of common concern and can prosper best by the combined active support of all. Provision is made under the new constitution for others, not members of the participating societies, to become associate members of the Institute.

It is intended, when sufficient finance is available, to establish an official monthly journal of the Institute, to be sent without additional charge to all members of the Institute. This journal will contain news about physicists, their meetings, work and other activities, and about similar features in related fields ; information about the action of government and other non-physical agencies affecting physics; articles and letters expressing views of physicists on problems of general importance; references to current literature in physics; book reviews, etc. When this journal, for which the title Physics has been suggested, appears, the Review of Scientific Instruments will revert to a journal devoted exclusively to the science of instruments. It is hoped that associate members, who will be recruited from the very large number of school teachers, students and others who have graduated in physics and thus have an interest in the subject, will be encouraged through the medium of the new journal to become members of one or more of the participating societies.

\section{Fresh Water Biology in Italy}

Founded in 1939 by private endowment, the Istituto Italiano di Idrobiologia de Marchi, at Pallanza (Province Novara), is scarcely known abroad. It is situated on the north shore of Lake Maggiore in one of the most suitable and beautiful sites for carrying out research and enjoying the surroundings. Its excellent equipment for field and laboratory research, its spacious accommodation and its sub-station-in a beautiful villa on Lake Comoprovide full facilities for any kind of limnological investigation on the great lakes at the foot of the Alps; and a number of smaller lakes all the way up the slopes of the Alps are within easy reach. The main activities of the staff are freshwater ecology, systematics and genetics, a series of papers having already appeared as the Institute's Memorie. Free lodging and free laboratory facilities are offered to foreign guests (up to five at one time). Other facilities may be arranged for by agreement with the director, Dr. E. Baldi. Pallanza is easily reached from either of the two international railways, the Simplon and the St. Gotthard.

\section{Radiolocation Convention Papers}

As already mentioned in Nature (February 1, p. 174), the Proceedings of the Radiolocation Convention held at the Institution of Electrical Engineers in 1946 are being published as a series of special numbers of Part 3 of the Journal of the Institution. Five such numbers have now been issued, and reference has already been made to the first two. No. 3 contains two papers dealing with some aspects of the propagation of radio waves overland in the wave-length range $10 \mathrm{~cm} .-10 \mathrm{~m}$. ; and nine papers describing the development for radar purposes of special aerial systems for use in the metre band of wave-lengths between $\mathbf{1 . 5}$ and 15 metres. The corresponding developments in aerial systems for centimetre wave-lengths are dealt with in a series of six papers forming part of the fourth number (Vol. 93, Part III A, No. 4) of this special publication.

Since it is in the centimetre range of wave-lengths that the wave guide replaces wire circuits and cables for connexions between different parts of the radiofrequency equipment and between the equipment and the aerial system, it is natural to find the twelve papers on wave guides also in this fourth special number. These papers deal with some of the problems involved in design and in the application of waveguide technique to very short wave radio equipment. The fifth number (Vol. 93, Part III A, No. 5) contains five papers on cathode-ray tubes and twelve on valves. In the first place, these describe some of the advances made in the use of cathode-ray tubes, with special screens in many cases, for radar display purposes. The second series of papers provides a comprehensive record of the special valve development conducted in Great Britain during the War, ranging from triodes for very short waves, the con. ception and development of that important device, the resonant cavity magnetron, to the high-power pulsed magnetron and the velocity-modulation reflexion oscillator. Since a crystal detector, now termed a crystal valve, is an essential part of all centimetre wave radio receivers, a paper on this subject is included in this particular number of the publication.

\section{National Museum of Wales}

THE report for 1946 of the National Museum of Wales again exhibits that activity of service (external as well as internal) which is conformable with the purport of a great institution. In this report the acquisition of St. Fagans Castle and grounds for use as a Welsh folk museum is fully discusscd; plans for its future organisation are outlined, and it is stated that part of the new folk museum and grounds will be ope ed to the public during the present year. An interesting development, and one which would seem to offer scope for the future, was the circulation in 1946 of a travelling exhibition of the Llyn Cerrig and Valley aerodrome finds-finds which had "excited so much interest throughout the Principality and especially in the island" (Anglesey). The exhibits were first set up at Holyhead, where an official lecture was given, then at Llangefni, and finally at Bangor. At each of the first two places it remained four weeks, and at Bangor for a longer period. It is of further interest that this movement was made in response to a request from the Anglesey Education Committee and the Committee of the Museum of Welsh Antiquities at the University College of North Wales, Bangor.

Departmental reports are primarily concerned with routine work, and the work of reorganisation which necessarily follows the return of collections from war-time storage. During the year some of the reference collections were again available for use. Those who believe in the practical educational value of museums under adequate schemes of organisation will be interested in the development regarding the proposed schools service mentioned on p. 20 of the report. This states that the Parliamentary Secretary to the Ministry of Education, Mr. D. R. Hardman, 
has visited the Museum as a result of a memorandum outlining a scheme which was presented to the Ministry in 1944, and "It is understood that the Ministry is now in consultation with Local Education Authorities in Wales on the matter". Appendixes at the end of the report include lists of acquisitions, publications by members of the staff during the year, and the usual list of the Museum's handbooks and guides.

\section{Waxwing Immigration}

THE severe winter of 1946-47 was marked in England by an abnormal immigration of waxwings (Bombycilla garrulus) and great grey shrikes (Lanius excubitor), particularly the former. Appearing near Edinburgh in November, flocks of waxwings quickly spread over the eastern counties of England in the latter months of 1946, and in late December appeared in Lakeland, where some flocks of more than twenty birds were noticed. In December and January several birds appeared in Lancashire and Cheshire, near Lancaster, Liverpool, Altrincham and Chester, and as usual in these immigrations the birds were attracted to berry-bearing shrubs and were exceedingly tame. There was a previous immigration of these noticeably brilliant birds into the eastern counties early in 1943; but they do not usually penetrate in such large numbers as occurred during the recent immigration into the western half of Britain. Nesting in North Europe, their irregular visitations to Britain were first recorded near York in 1681 (Phil. Trans. Roy. Soc.). Odd birds occur almost every winter in Scotland, but Irish records are much fewer than those in England.

\section{Proceedings of the Tenth International Congress of Chemistry}

THE full Proceedings of the Tenth International Congress of Chemistry, which was held in Rome in May 1938 under the presidency of the late Prof. Nicola Parravano, were published in five volumes in Italy during the years 1938-39. Owing to the outbreak of war, many libraries in Great Britain and elsewhere will have failed to receive complete sets of this important publication, and they will be glad now to learn that copies of the five volumes are still available. Full particulars may be obtained from Prof. Guido Bargellini, Istituto Chimico, Città Universitaria, Rome, to whom also orders for any of, or all, the volumes should be addressed.

\section{Lord Kelvin and the British Metrical System}

ON June 2, 1897, in his well-known address to the Victoria Institute on "The Age of the Earth", Lord Kelvin said: "I must first ask you to excuse my giving you all my depths, heights, and distances, in terms of the kilometre, being about six-tenths of that very inconvenient measure the English statute mile, which with all the other monstrosities of our British metrical system, will, let us hope, not long survive the legislation of our present Parliamentary session destined to honour the sixty years' Jubilee of Queen Victoria's reign by legalising the French metrical system for the United Kingdom". The Weights and Measures (Metric System) Act was passed, and it is no longer a punishable offence for a tradesman to have in his possession a weight or measure of the decimal system. But with all the "monstrosities of our British metrical system" still surviving, it is interesting to recall the fiftieth anniversary of Lord Kelvin's unfulfilled hope.

\section{Announcements}

DR. T. F. WEST, author of papers on D.D.T., has been appointed an assistant director of the Ontario Research Foundation, and will leave London to take up his duties in Canada in July.

Dr. D. W. Davison, of the physics staff of the Brown-Firth Research Laboratories (Thos. Firth and John Brown, Ltd., Sheffield), has been appointed a senior research officer, Council for Scientific and Industrial Research, Australia, in the Research School of Metallurgy at the University of Melbourne, where he will join a team working on the physies and crystallography of ferrous and non-ferrous metals, under Prof. J. Neill Greenwood.

Sir RoBert Robinson, president of the Royal Society, will open a new research laboratory in the Department of Chemistry, University of Glasgow, on June 25; the laboratory is to bear the name of G. G. Henderson.

As a result of a meeting of mycologists and plant pathologists at the Indian Agricultural Research Institute, New Delhi, on February 28, the Indian Phytopathological Society was initiated. All persons interested in the study of fungi, bacteria and viruses are invited to join the Society. Further information can be obtained from the SecretaryTreasurer, Indian Phytopathological Society, Agricultural Research Institute P.O., New Delhi.

THE report of the Conference on "Research and the Smaller Firm" arranged by the Manchester Joint Research Council last October (see Nature, 158, 638 ; 1946), which has now been published (from the Manchester Chamber of Commerce. 2s. 6d.), includes an account of the proceedings of the Conference with a full report of the discussions at both sessions. The papers by Mr. C. E. Renold, Dr. C. J. T. Cronshaw and Dr. F. C. Toy are appended, with written contributions from Mr. H. Downs and Mr. J. Williams and a note on the Manchester Federation of Scientific Societies.

Detams of the Industrial Film Service of the Blackheath Film Unit (9 North Street, Leatherhead), which has already been responsible for such outstanding films as "Training of the Disabled", for the Ministry of Labour and National Service, and "Sugar Beet", for the Ministry of Agriculture, are outlined in a sixteen-page brochure issued by the Unit. The Unit is equipped and staffed to undertake the production of any type of industrial or instructional film, and can also provide a complete technical service to the film units of its clients.

THe Göteborgs Högskola has awarded the Heyman Prize (value about $£ 700$ ) to Börje Kullenberg, in recognition of his distinguished work in constructing the piston core-sampler, which has provided the means for a new departure in submarine geology. The piston core-sampler has proved capable of securing practically undisturbed sediment profiles up to 20 metres in length. It was used with great success on the Skagerak Expedition to the western Mediterranean during April-May 1946, when long cores were obtained down to a maximum depth of $3,600 \mathrm{~m}$. It will be used from the coming Swedish circumnavigating deep-sea expedition with the Albatross. The Heyman Prize is given at intervals of three years, for literature and for science alternately. In 1941 the first science award was divided between the two eminent Swedish geologists, Helge Backlund and Lennart von Post. 